University of Nebraska - Lincoln

DigitalCommons@University of Nebraska - Lincoln

\title{
Paleoclimate Reconstruction Along The Pole-Equator-Pole Transect of the Americas (PEP 1)
}

\author{
Vera Markgraf \\ Institute of Arctic and Alpine Research, University of Colorado. Boulder CO 80309-0450, USA
}

T.R Baumgartner

Scripps Oceanographic Institute, La Jolla CA 92093, USA

J. P. Bradbury

US Geological Survey, Denver Federal Center, MS 980, Denver Co 80225, USA

H. F. Diaz

National Oceanographic and Atmospheric Administration, Climate Diagnostic Center, 325 Broadway,

Boulder CO 90303, USA

R. B. Dunbar

Department of Geological and Environmental Sciences, Stanford University, Stanford CA 94305-2115, USA

See next page for additional authors

Follow this and additional works at: https://digitalcommons.unl.edu/usgsstaffpub

Part of the Earth Sciences Commons

Markgraf, Vera; Baumgartner, T.R; Bradbury, J. P.; Diaz, H. F.; Dunbar, R. B.; Luckman, B. H.; Seltzer, G. O.; Swetnam, T. W.; and Villalba, R., "Paleoclimate Reconstruction Along The Pole-Equator-Pole Transect of the Americas (PEP 1)" (2000). USGS Staff -- Published Research. 249.

https://digitalcommons.unl.edu/usgsstaffpub/249

This Article is brought to you for free and open access by the US Geological Survey at DigitalCommons@University of Nebraska - Lincoln. It has been accepted for inclusion in USGS Staff -- Published Research by an authorized administrator of DigitalCommons@University of Nebraska - Lincoln. 


\section{Authors}

Vera Markgraf, T.R Baumgartner, J. P. Bradbury, H. F. Diaz, R. B. Dunbar, B. H. Luckman, G. O. Seltzer, T. W. Swetnam, and R. Villalba 


\title{
Paleoclimate reconstruction along the Pole-Equator-Pole transect of the Americas (PEP 1)
}

\author{
Vera Markgraf $^{\mathrm{a}, *}$, T.R Baumgartner ${ }^{\mathrm{b}}$, J. P. Bradbury ${ }^{\mathrm{c}}$, H. F. Diaz ${ }^{\mathrm{d}}$, R. B. Dunbar ${ }^{\mathrm{e}}$, \\ B. H. Luckman ${ }^{\text {, G. O. Seltzer }}$, T. W. Swetnam ${ }^{\text {h }}$, R. Villalba ${ }^{\mathrm{i}}$ \\ ${ }^{a}$ Institute of Arctic and Alpine Research, University of Colorado. Boulder CO 80309-0450, USA \\ ${ }^{\mathrm{b}}$ Scripps Oceanographic Institute, La Jolla CA 92093, USA \\ ${ }^{\mathrm{c}}$ US Geological Survey, Denver Federal Center, MS 980, Denver CO 80225, USA \\ ${ }^{\mathrm{d}}$ National Oceanographic and Atmospheric Administration, Climate Diagnostic Center, 325 Broadway, Boulder CO 90303, USA \\ ${ }^{\mathrm{e}}$ Department of Geological and Environmental Sciences, Stanford University, Stanford CA 94305-2115, USA \\ ${ }^{\mathrm{f}}$ Department of Geography, University of Western Ontario, London, Ont, Canada, N6A 5C2. \\ ${ }^{\mathrm{g}}$ Deptarment of Earth Sciences, Syracuse University, Syracuse NY 13244, USA \\ ${ }^{\mathrm{h}}$ Tree Ring Laboratory, University of Arizona, Tucson AZ 85721, USA \\ ${ }^{\mathrm{i}}$ Tree Ring Laboratory, IANIGLA-CRICYT, c.c. 330, 5500 Mendoza, Argentina
}

\begin{abstract}
Examples are presented of inter-hemispheric comparison of instrumental climate and paleoclimate proxy records from the Americas for different temporal scales. Despite a certain symmetry of seasonal precipitation patterns along the PEP 1 transect, decadal variability of winter precipitation shows different characteristics in terms of amplitude and frequency in both the last 100 and last 1000 years. Such differences in variability are also seen in a comparison of time series of different El Niño/Southern Oscillation proxy records from North and South America, however, these differences do not appear to affect the spatial correlation with Pacific sea surface temperature patterns. Local and regional differences in response to climate change are even more pronounced for records with lower temporal resolution, and inter-hemispheric synchroneity may or may not be indicative of the same forcing. This aspect is illustrated in an inter-hemispheric comparison of the last 1000 years of glacier variability, and of the full- and lateglacial lake level history. (C) 1999 Elsevier Science Ltd. All rights reserved.
\end{abstract}

\section{Introduction}

The International Geosphere-Biosphere Program on Past Global Change (IGBP-PAGES) has taken on the challenge to provide global evidence of natural climate variability and its forcing in order to establish a framework for society and its decision makers of how best to prepare for future change. Because no single record can adequately represent past global climate change, regional paleoclimate evidence from both the ocean and land must be assembled and integrated. Integration of such evidence must be based on an understanding of both the specific responses of regional environmental systems to climate change, and the climatic linkages between the different regions and systems.

\footnotetext{
*Corresponding author. Tel.: + 1-303-4925117; fax: + 1-3034926388.

E-mail address: markgraf@spot.colorado.edu (V. Markgraf)
}

The Pole-Equator-Pole (PEP) initiatives represent an international effort to integrate records along longitudinal transects in order to focus on the interhemispheric linkages of climate, present and past. The Americas transect (PEP 1) is optimal for an interhemispheric comparative study of paleoclimate change for three primary reasons: the symmetry of the North and South American land areas, the presence of a continuous series of longitudinal mountain ranges along the western continental margin of the Americas, and their position at the eastern margin of the Pacific Ocean. Along this transect the land areas have broadly similar poleward extent, similar distribution of mountains and lowlands, and similar dynamic responses to atmospheric and surface ocean forcing. By combining understanding of modern processes with paleoclimatic evidence from marine and terrestrial records a holistic view of change should emerge, leading to a better understanding of mechanisms and forcing of climate change. 
Based on presentations at a recent PEP 1 meeting in Merida, Venezuela (Markgraf, 1998), examples are presented here that illustrate inter-hemispheric climate linkages in the Americas, present and past, at time scales ranging from years to decades, centuries and millennia. Evidence used for this inter-hemispheric comparison addresses climate variability in the instrumental record, in climate proxy records that relate to El Niño/Southern Oscillation (ENSO) variability, in records showing the history of glacier movements during the last 1000 years, and in records of lake levels during late Pleistocene and Holocene times.

\section{Precipitation seasonality during the last 1000 years}

Before information from the instrumental climate record can be applied to paleoclimate evidence, it is necessary to evaluate whether recent climatic changes are unique in their spatial and temporal characteristics. In particular it would be important to know how persistent patterns are on different temporal scales, especially at decadal to century time scales. Analysis of different climate parameters has shown, e.g., that not only inter-annual, ENSO related variability, but also variability at decadal scales (40-500 yr) is indicative of oceanatmosphere linkages (Stocker and Mysak, 1992), at time scales that are of great interest for low-resolution paleoclimate studies.

The examples presented here are time series of seasonal precipitation. Changes in the seasonality of precipitation (as well as temperature) are considered an important signal of climatic variation, especially because many paleoclimate proxy indicators respond to changes in seasonality. An analysis of the instrumental record of precipitation for those regions in the Americas receiving most of their annual precipitation during the winter half-year (Fig. 1) shows that the North American region $(\mathrm{NH})$ has seen little or no long-term trend in December-February values over the last century (see Dettinger et al., 1998). However, significant decadal-scale variability in winter precipitation is present, with nearly $40 \%$ of the total inter-annual variance contributed by decadalscale variations during the period of record. By contrast, the South American region (SH) record of June-August precipitation departures from a 1951-1980 reference period (see map in Fig. 1), shows some decline in the amplitude of values in the more recent decades, and slightly higher decadal-scale variability as a fraction of total variance $(40 \%$, versus $38 \%$ for the $\mathrm{NH})$.

Does this imply that the instrumental time series is too short to detect persistence of patterns or trends that would help to interpret past climate change patterns? One approach to test this question is to extend the record back in time, using annually laminated records such as tree rings or laminated sediments. For the same winter rain regions discussed, California and Chile, tree ring records, sensitive to precipitation changes, extend the time series back to AD 800 and AD 1220, respectively (Diaz and Pulwarty, 1994). The decadal characteristics seen in the last 100 years of instrumental record apparently holds up at the longer time scales. The Californian winter precipitation record shows at the $11-25 \mathrm{yr}$ and 25-150 yr bands generally higher frequency and amplitude of variability than the Chilean record (Fig. 2). Amplitude of precipitation excursions in the $\mathrm{SH}$ record on the other hand, especially in the $25-150 \mathrm{yr}$ band, is at times larger than in the NH. A comparison of the variations during different centuries indicates that there are significant differences in the expression of variance on decadal and longer time scales at different times in the past. This difference needs to be taken into account when e.g. comparing paleo-precipitation records from both regions.

\section{El Niño-Southern Oscillation Climate Variability}

Inter-hemispheric climate anomalies in the Americas are clearly associated with the inter-annual ENSO phenomenon. On timescales longer than inter-annual, the dominant climate pacemaker in the Pacific Ocean and overlying atmosphere also has an ENSO-like spatial distribution. While the physical mechanisms responsible for decadal ENSO-like variability are not known, the resulting climate anomalies are significant. Furthermore, the inter-annual ENSO and decadal ENSO-like phenomena are associated with qualitatively different climate anomalies in the mid and high latitudes of the Americas. A variety of archives are used to examine past variability in the inter-annual ENSO and decadal ENSO-like phenomena, including annually laminated marine sediments, tree ring records, and fire history data. A new sub-annual coral record from the Galapagos Islands provides an absolutely dated (and cross-dated) record of Eastern Pacific Cool Tongue temperature extending back to the middle 1800s. This new record shows strong coherence with ENSO-recording coral sites in the central and western Pacific and further documents the links between climate variability at inter-annual and near-decadal timescales.

Contributions analysing paleoclimate records in context of understanding past expression of ENSO address the following questions: (1) past variability in ENSO forcing, (2) changing teleconnection patterns within the Americas, and (3) interactions of ENSO with other climate systems on decade-to-century timescales.

\subsection{High-Resolution Marine Records}

Climate proxy records have been developed that cover the past 2000 years with inter-decadal resolution (with an 


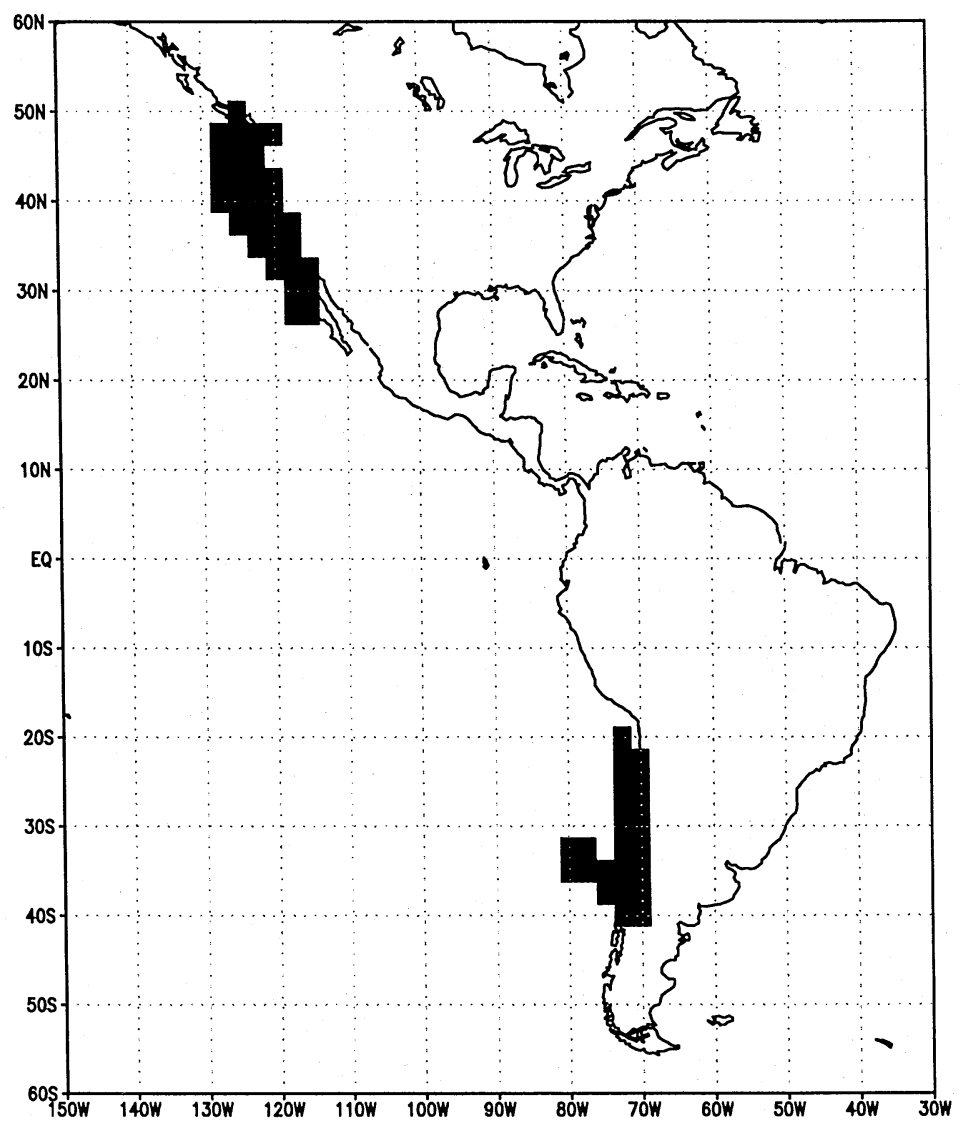

$\mathrm{NH}$ Winter Season Peak D.F Precipitation Departures

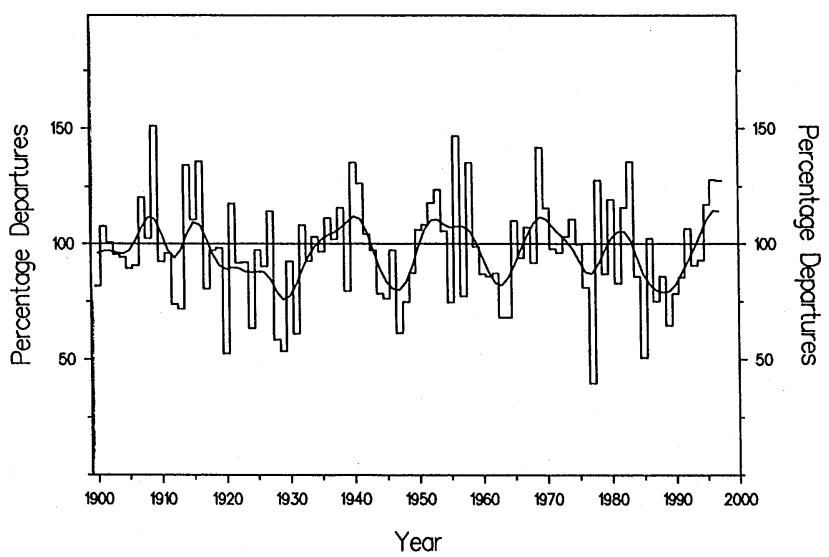

SH Extratropics Winter Season Peak JJA Precipitation Departures

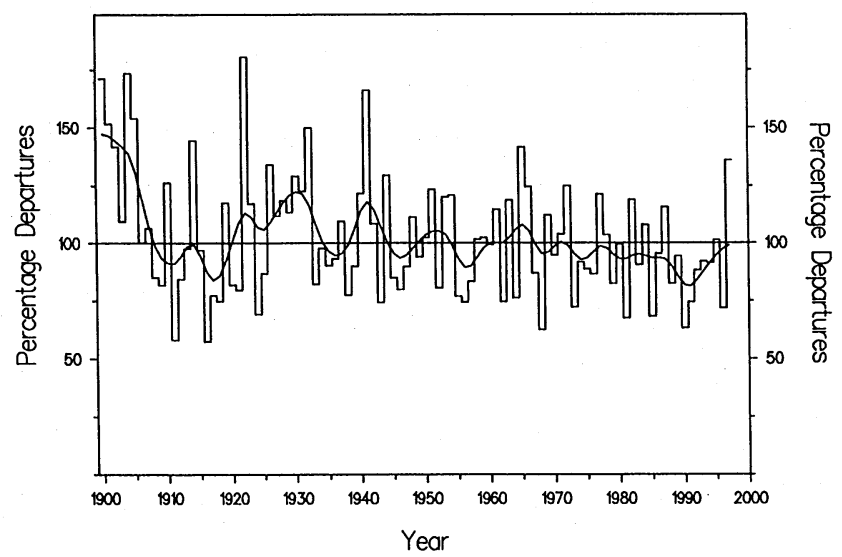

Fig. 1. Time series of winter precipitation for two regions in the Western Hemisphere with a seasonal maximum of precipitation occurring during their respective winter months (bottom graphs). Map shows the geographical areas encompassed by the two regions.

accuracy within \pm 5 calendar years in 1000 years of record) to inter-annual resolution ( $\pm 2 \mathrm{yr}$ ) from multiple sites of suboxic deposition along the western margins of North and South America, in the California and Humboldt Current systems, respectively (Fig. 3). Four sites are under development in the eastern North Pacific Ocean: (1) Effingham Inlet, located on the west coast of Vancouver Island, Canada (discovered December, 1995);
(2) the Santa Barbara Basin off Southern California, USA; (3) Soledad Basin off the west coast of southern Baja California, Mexico; and (4) the Guaymas slope off mainland Mexico in the Gulf of California.

Identification and development of sites in the Humboldt Current lags behind those in the California Current, but near-coastal sites with strong potential have been identified off central and southern Peru, off 
northern and central Chile (Ortlieb et al., in press, Gutierrez, personal communication), and there are possible sites in the Fjords of southern Chile (Salamanca, personal communication.). There are two known sites off Peru with continuous, detailed records of the past 100 years (Callao at $12^{\circ} \mathrm{S}$ ) and of the last 150 years (Pisco at $\left.15^{\circ} \mathrm{S}\right)$. The presence of coherent, lower resolution records off northern Chile hold the promise for developing higher resolution records for the past 2000 years for this region.

Of particular interest is to reconstruct the inter-decadal variability in ocean climate associated with an "ENSO-like" signature (Zhang et al., 1997). This ENSOlike signature is characterized by climate regime shifts between tropical warming and cooling which persist for several decades. The most recent shift of the 1970s brought anomalous inter-decadal-scale warming to the central and eastern tropical Pacific which extended poleward along the eastern boundaries of both the North and South Pacific. Reconstruction of this variability as preserved in the sediments under the California and Humboldt systems provides a means to determine the extent to which the synchroneity in ocean climate bet- ween the North and South Pacific-Oceans, apparent in the instrumental record of inter-decadal variability, has been maintained over the past 2000 years, and to examine the interaction between inter-decadal and centennial variability.

One of the principal tools to be developed as a climate proxy in this context is the accumulation rates of fish scales of schooling pelagic fish species like sardines and anchovies which form a principal trophic link in the ecology of these two current systems. Basin-wide "ENSO-like" ocean climate change results in the latitudinal expansion and contraction of suitable habitat, with associated increases/decreases in abundance of these populations. It is therefore possible to reconstruct not only a temporal record of change, but we hope to be able to develop also histories of space-time variability of the coastal pelagic environment within each current system using the latitudinal comparison of sites through time. The best-developed record of these populations so far is the 1600-year history from the Santa Barbara Basin off California (Soutar and Crill, 1977; Soutar and Isaacs, 1974). Shorter records in the North Pacific Ocean are becoming available now from Effingham Inlet (for

\section{SIERRA NEVADA PRECIP. AD800-1987}

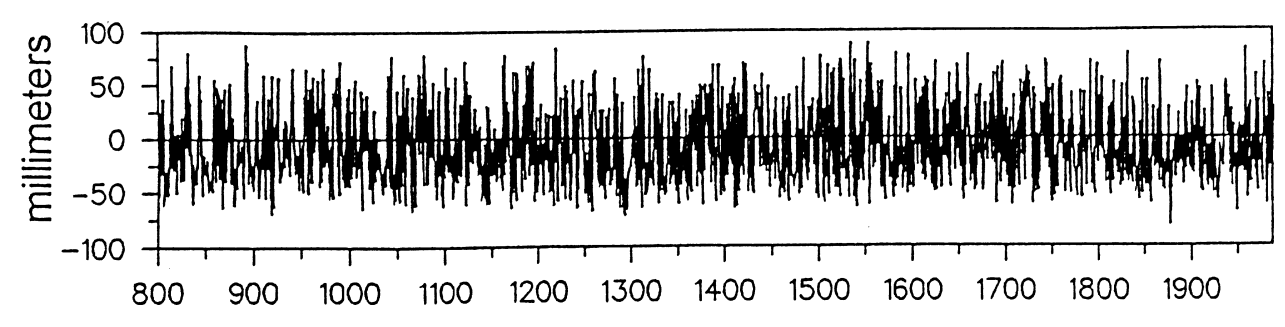

SIERRA NEVADA 25-150 YR

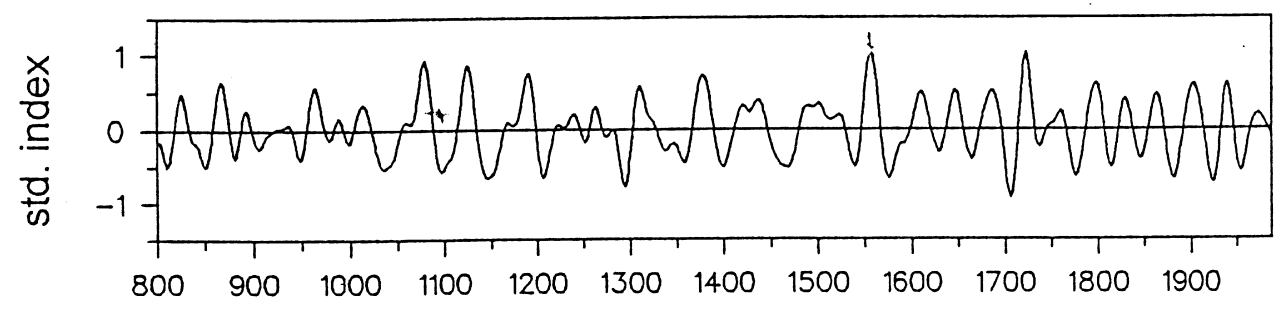

SIERRA NEVADA 11-25 YR

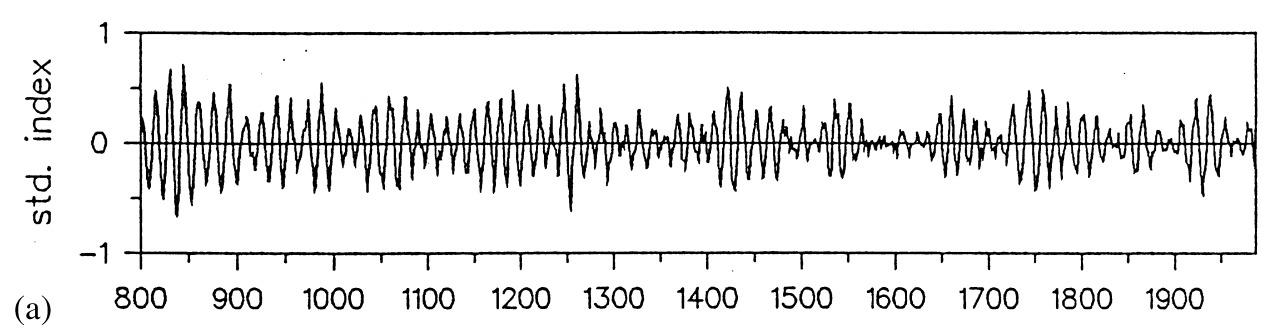

Fig. 2. Original and filtered values (25-150 and 11-25 yr filter) of tree ring records from (a) Sierra Nevada, California (subalpine conifers: Pinus balfouriana and Juniperus occidentalis ssp. australis) and (b) Santiago, Chile (Austrocedrus chilensis). Modified from Diaz and Pulwarty, 1994. 


\section{SANTIAGO WINTER RAIN AD1220-1972}

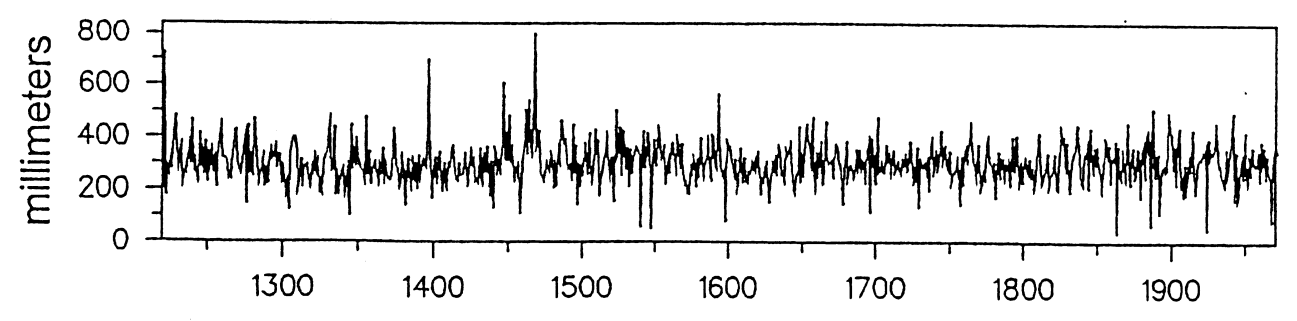

\section{SANTIAGO 25-150 YR}

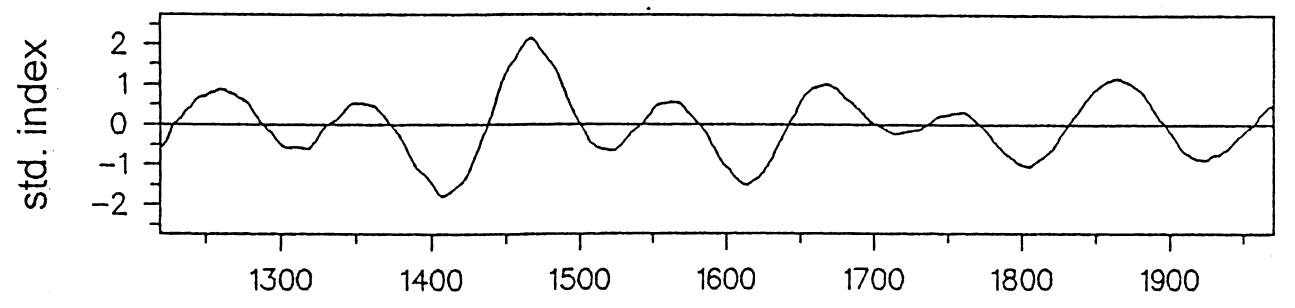

SANTIAGO 11-25 YR

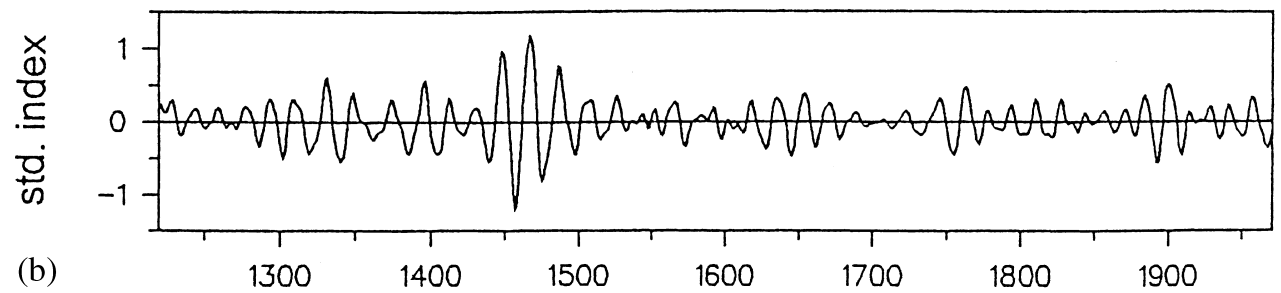

Fig. 2. (Continued)

approximately the last 500 years), for the Soledad Basin (200 years) and for the Gulf of California (200 years).

The Santa Barbara Basin site contains an excellent record of fish scale deposition which allows us to reconstruct the population biomass by calibration to modern records (Baumgartner et al., 1991,1992). These biomass records provide extraordinary time series that record the population response to environmental forcing. The Santa Barbara record provides an example of the value of the scale-deposition records to determine the predominant modes of variability in the coastal pelagic habitat. The analysis of the nature of this variability is shown for the sardines and anchovies in Fig. 4. The biomass series is resolved into 5-year intervals and partitioned into its high-frequency (limited to $<90$-yr periods) and low-frequency components ( $>90-y r$ periods). The variance spectra of the high-frequency components are shown in Fig. 5. Although the spectra of both species show several important periods of variability, the predominant time scale of expansion and contraction of these populations is on the order of 50-60 yrs for sardines and approximately $30 \mathrm{yr}$ for the anchovies. Because the sardines are particularly sensitive to temperature the dominant period of inter-decadal warming or cooling of the coastal ocean of the northeastern Pacific Ocean appears to have occurred around the mean period of 50-60 yr. The low frequency series of the reconstructed sardine biomass shows considerable variability at the multi-centennial scale of 500-600 yr. Warming (high biomass) and cooling (low biomass) periods appear to roughly coincide with major modes of Northern Hemisphere climate such as the Little Ice Age and the Medieval Warm Period.

\subsection{Tree-Ring Records}

One of the most promising developments with respect to ENSO is a new technique for climate field reconstruction from a sparse observational network using reducedspace objective analysis. The procedure produces theoretical errors for the reconstructions and permits several verification procedures. As an example, tree ring chronologies from the Pacific coasts of the Americas were used to reconstruct the sea surface temperature anomaly field for the period AD 1-1990. Preliminary verification suggests that the NINO3 index estimated from this analysis is useful for about the last four centuries. 


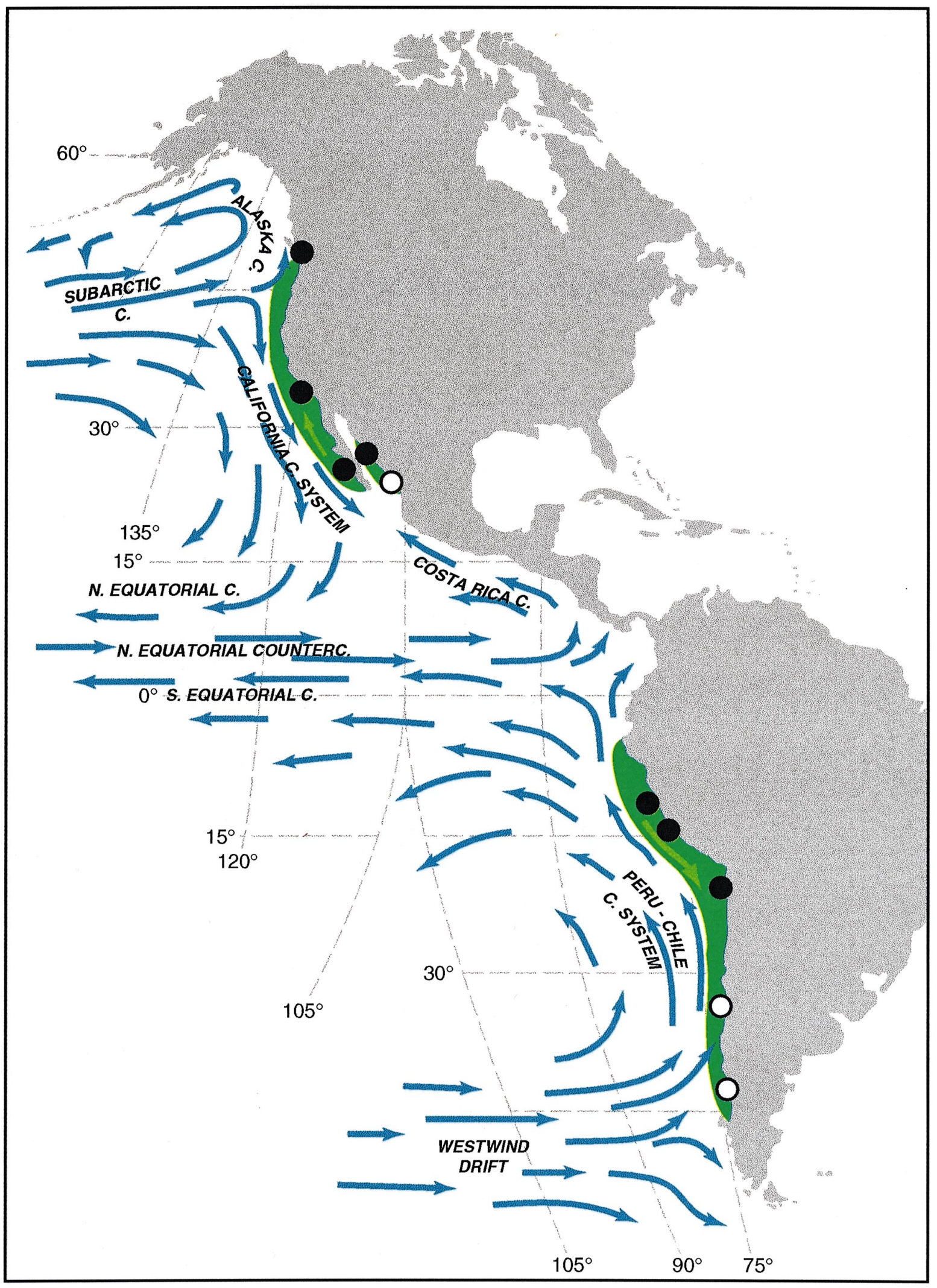

Fig. 3. Location of known (filled circles) and potential (open circles) sites with high-resolution records of ocean-climate variability of the California Current System (and Gulf of California), and in the Peru-Chile Current System. These sites are all located in coastal or near coastal environments of suboxic deposition. In the Northern Hemisphere, the sites are: Effingham Inlet (British Columbia, Canada), the Santa Barbara Basin (southern California, USA), Soledad Basin (southern Baja California, Mexico), Guaymas slope and Mazatlan slope (Gulf of California, Mexico). In the Southern Hemisphere the sites are: shelf off Callao (central Peru), shelf off Pisco (south-central Peru), shelf off Antofagasta (northern Chile), shelf off Concepción (central Chile), and the northern most fjords in southern Chile. 

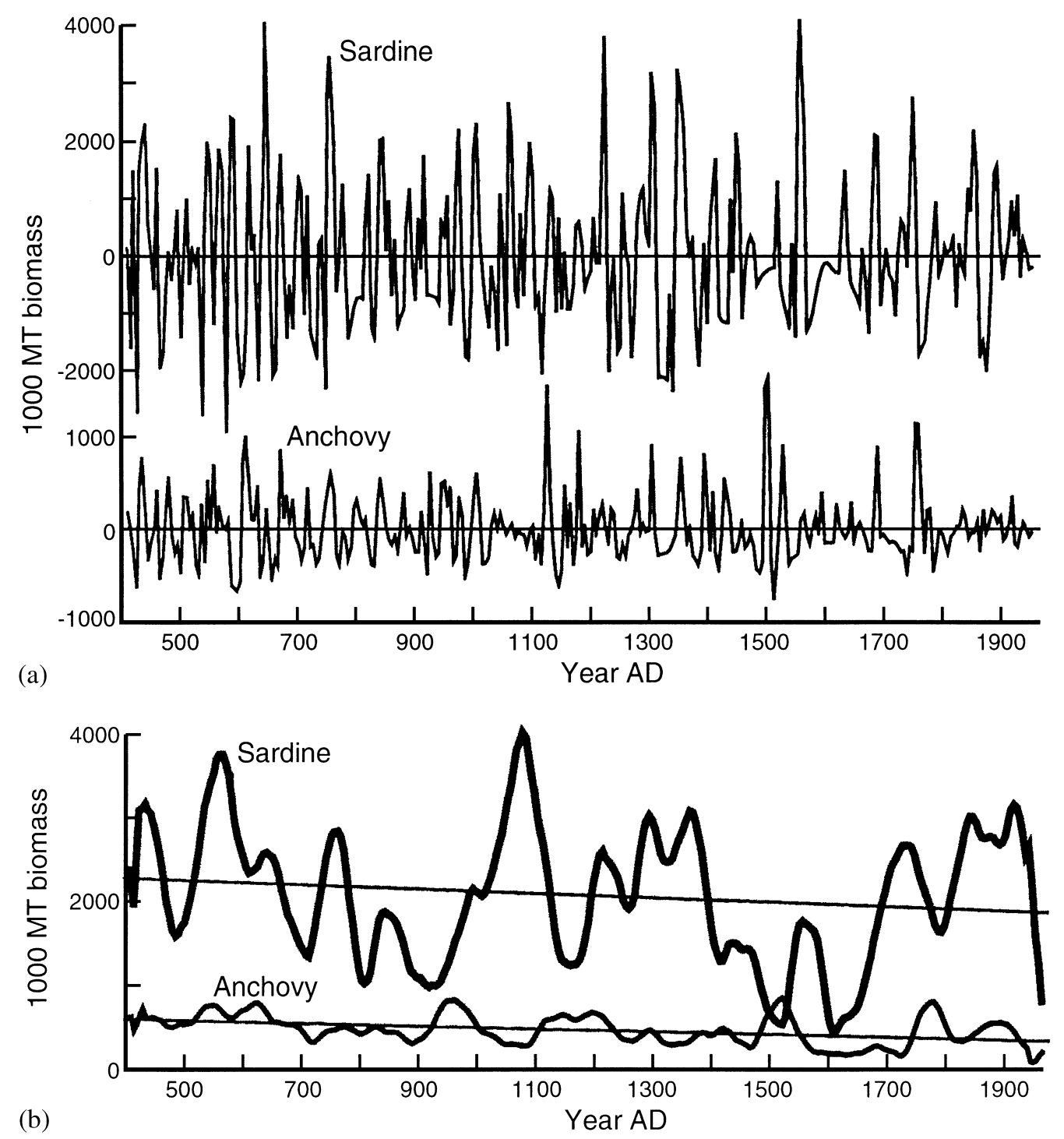

Fig. 4. Reconstructed time series of biomass for the sardine and anchovy populations in the California Current, partitioned into (a) high-frequency and (b) low-frequency components. The biomass reconstructions are based on calibration of 5-yr averages of fish-scale-deposition rates in the Santa Barbara Basin sediments to estimates of population biomass in the central region of the California Current from 1935-1970. Separation of the series into their component frequencies indicates the distinct modes of variability over inter-decadal and centennial time scales. The low-frequency component was obtained by low-pass filtering to remove all periods shorter than $100 \mathrm{yr}$ from the data. The high-frequency component is the difference between the unfiltered series and the low-frequency curve. Very-low-frequency (millennial scale) change in both the sardine and anchovies is denoted (in b) by the long-term trendlines.

ENSO-like inter-decadal variations of climate are illustrated via co-spectral analysis of temperature sensitive tree-ring chronologies from Alaska and Patagonia (Villalba et al., 1999). For the common interval of A.D. 1591-1988, the amplitudes from the first principal components of the Alaska chronologies are significantly correlated with those from Patagonia, which may be considered as a first indication of a common climatic forcing affecting both regions. Cross-spectal analysis of both the Alaska and Patagonian records indicates significant coherence at 10-15 yr and at temporal scales longer than 50 years. Additional, less prominent peaks are also observed at 2, 3.2, and 5.2 yr. From instrumental climate records, the 3.2 and 5.2 oscillation have largely been associated with the inter-annual mode of ENSO variability (Mann and Park, 1994).

When comparing the time series of the decadal and century-scale oscillatory modes that principally contribute to the positive correlation between the Alaska and Patagonian temperature-sensitive records, it appears that the relationships prior to 1850 are more consistent than afterwards. An explanation could relate to differences in the amplitude of ENSO oscillations, with a lowfrequency (or amplitude) inter-annual ENSO mode 


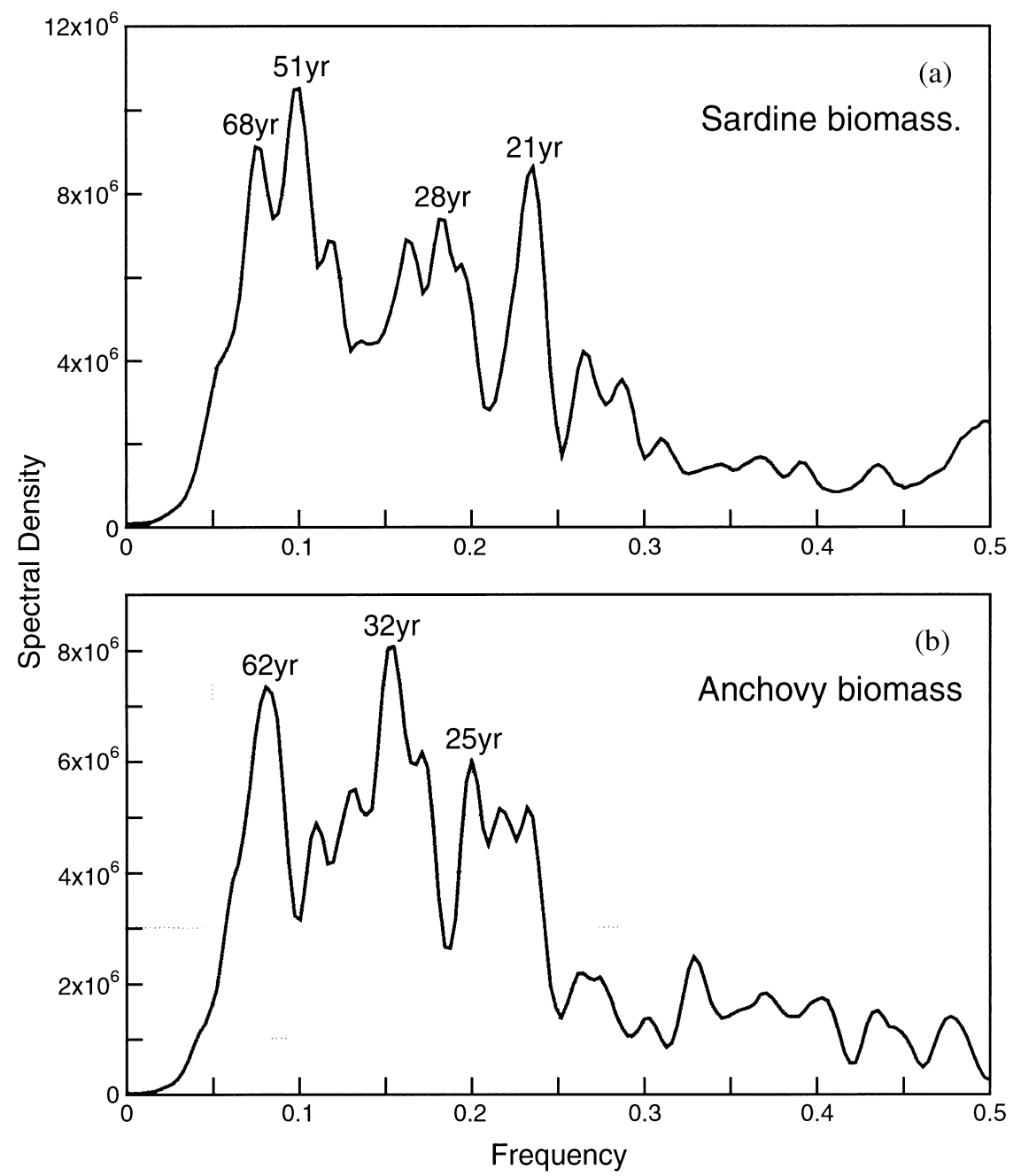

Fig. 5. Variance spectra of the high-frequency component (Fig. 2a) in the reconstructed biomass series for the (a) sardine and (b) anchovy. The sardine biomass shows the variance concentrated mainly in a broad peak between 50 and $70 \mathrm{yr}$ and a second important peak around $20 \mathrm{yr}$. A third smaller sardine peak falls in the range of 25-30 yr. The anchovy spectrum shows a large peak around $30 \mathrm{yr}$ with less, but still important concentration of variance at roughly $60 \mathrm{yr}$ and $20-25 \mathrm{yr}$ periods.

dominant prior to 1850 and a high-frequency (or amplitude) mode since that time.

To establish a spatial relationship between the temperature-sensitive records from Alaska and Patagonia with Pacific SSTs, correlation fields were calculated between tree-ring variability and annual SSTs for the interval 1857-1988, using data from Kaplan et al. (1997). The two spatial patterns that emerge are qualitatively similar, with positive correlations in the tropical Pacific Ocean and a mid to high latitudes along the west coasts of the Americas, and negative correlations in the extratropical central and western Pacific Ocean (Fig. 6). This suggests Pacific Ocean forcing of land temperatures in both regions. Common modes of variance at periods of $\sim 8$ and 10-18 yr are also observed when precipitation-sensitive chronologies from the southwestern US are compared with those from Central Chile, also the suggested result of modulation by Pacific ENSO-like phenomena. All tree-ring records show changes in oscillatory modes around 1850, which may be related to reorganization in the circulation of the Pacific Ocean at that time.

\subsection{Fire history record}

One of the most dramatic and important ways that climatic change can affect ecosystems is by altering the frequency, intensity, and extent of forest fires. The role of ENSO in modulating fire regimes at global scales is suggested by the occurrence of enormous wildfires in Indonesia, Australia, Central America, and Amazonia during the recent El Niño events of 1982-1983 and 1997-1998. Similar teleconnections in the temperate zones of the Americas indicate that regional forest fire regimes may be phase-locked with the Southern Oscillation (SO) (Swetnam and Betancourt, 1990,1998, Kitzberger and Veblen, 1998; Veblen et al., 1999). 

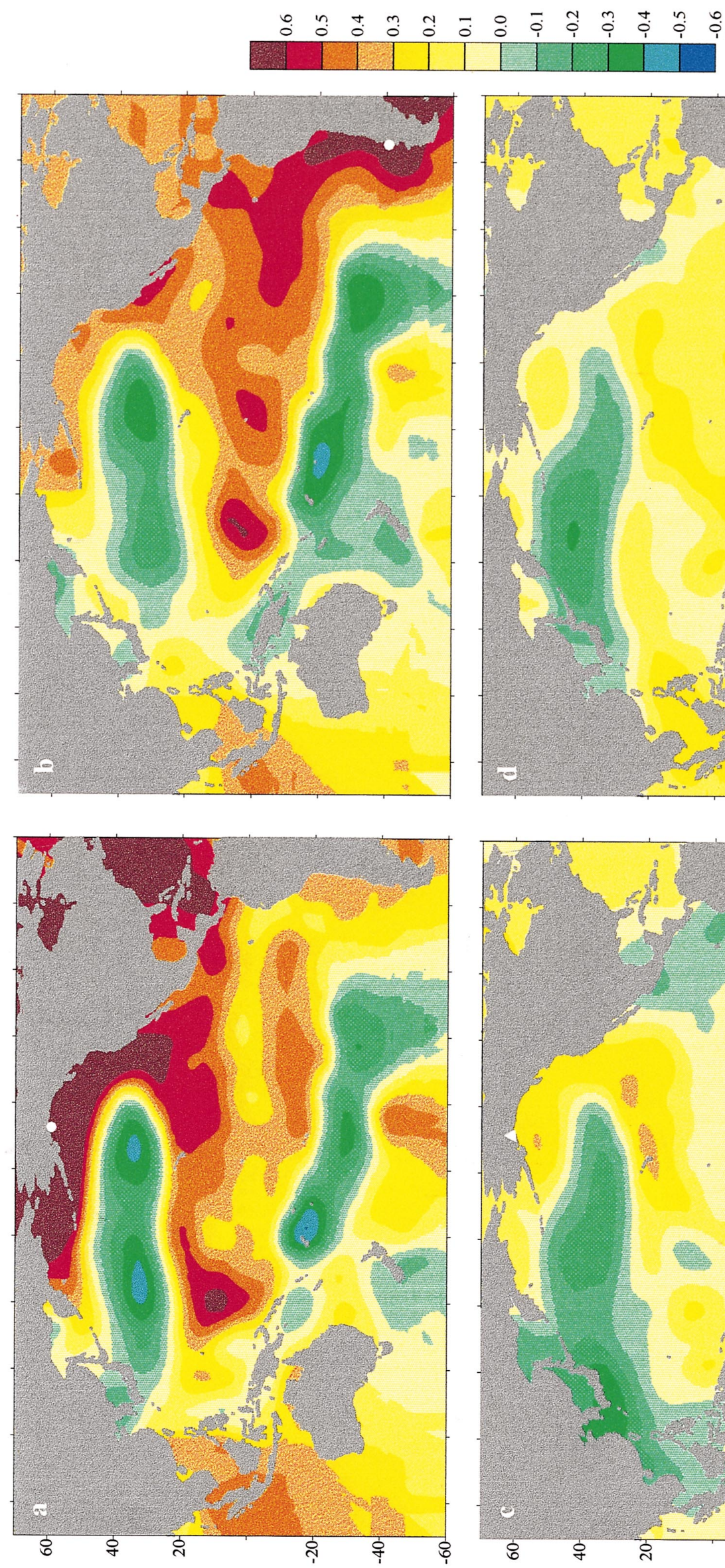
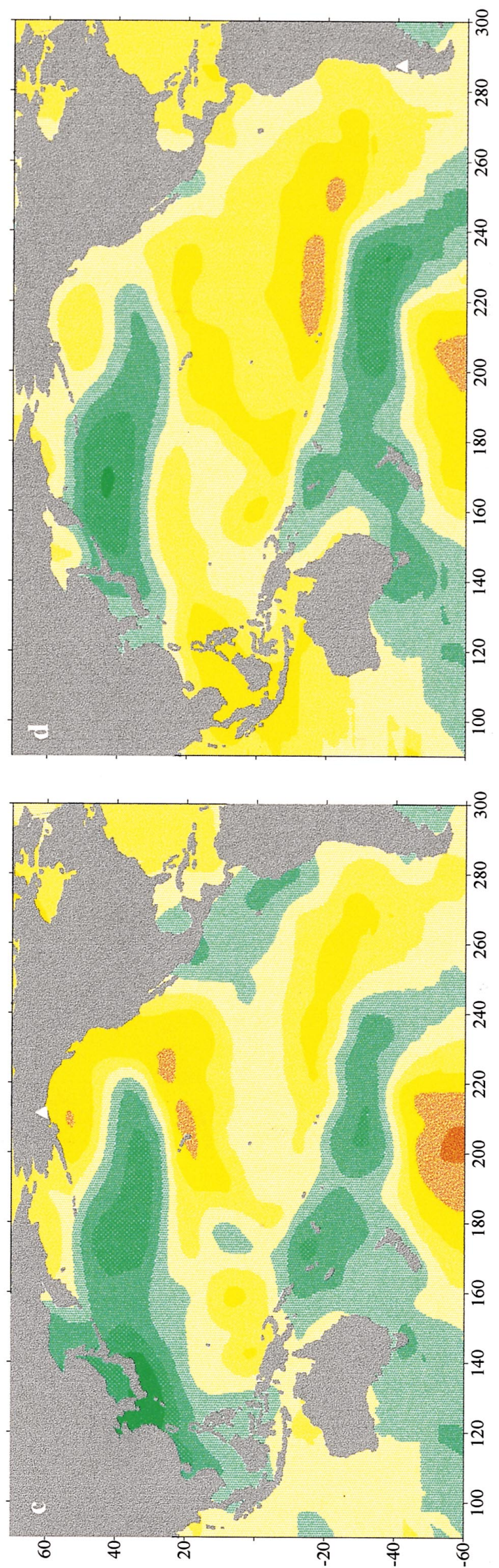

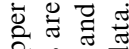

宝

.

ป

边茫

突焉吾:

의 $\Xi$

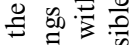

$\Xi$ :

过

苗

$>\infty \underbrace{\infty} . \Xi$

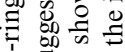

过 के

氙苛

芯芯志

రั

矛渮

空类

of of

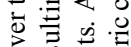

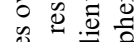

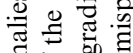

등

芯司章

领

믐

芯导吾

它焉

可论

过

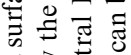

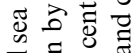

폴

灵

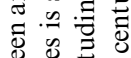

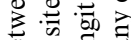

过

$\infty \vdots \bar{\Xi}$

$1 \pm$ 至

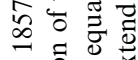

중의

氖

.

吉睼

总芯

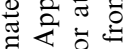

氙守 吾

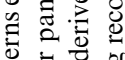

更

를

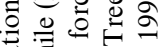

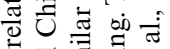

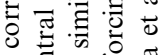

त 000

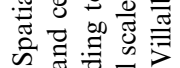

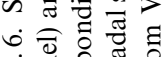

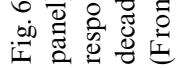


Extensive tree-ring reconstructions of forest fire history in the Southwestern US and northern Patagonia, Argentina, have recently been compiled and compared by T. Kitzberger (Universidad Nacional del Comahue, Argentina), T. W. Swetnam (University of Arizona, USA), and T.T. Veblen (University of Colorado, USA). Both regional reconstructions extend back more than three centuries. Comparisons of the regional time series indicate that they are spectrally coherent within the dominant ENSO frequency band (i.e., 2-7 yr), with similar inter-annual and decadal changes in fire frequency. Synchronous decadal-scale shifts in fire frequency correspond to independently reconstructed changes in the modal frequencies or amplitudes of the Southern Oscillation.

A combination of human impacts on ecosystems and climatic change are of critical concern in both the tropical and the temperate zones. It is not surprising that people would exploit unusual drought conditions to clear and burn tropical forests for agricultural purposes. Loss of ecosystems and biodiversity, and globally significant input of greenhouse gases and aerosols into the atmosphere, make these events of concern to all nations. Another problem is that fuels have accumulated in many forests and woodlands of the temperate zones because of fire suppression during the 20th century. Unusually frequent El Niño events (delivering extra moisture to some regions) during the past several decades may also be involved in creating an increasingly explosive fire situation by contributing to fuel accumulation. The tree-ring studies show that a sequence of extreme El Niño events followed closely by La Niña conditions are a typical combination promoting regional fire years in the South- western US and northern Patagonia. Moreover 20th century records reveal that these patterns typically precede the affected fire seasons by months to years (see Fig. 7), offering a window of opportunity for planning and action. Preventive measures and fire fighting readiness might reduce the occurrence and mitigate the effects of large, high-intensity fire events in the future, but only if decision makers are alerted to the hazards beforehand. These findings underscore the ecological importance of changes in the variability of the ENSO system, and the potential to use knowledge of inter-hemispheric ENSO-fire teleconnections to anticipate regional fire events.

\section{Little Ice Age Glacier History}

The geological/historical record of alpine glacier fluctuations has traditionally been used as a framework for climate history over the last millennium. However as new high-resolution paleoclimate records become available the dating and climate signal in this record must be more closely scrutinised. Luckman and Villalba (1999) critically reviewed and evaluated the glacier record along the PEP-1 transect using a range of examples. Surface morphological records only provide details of the last glacier event and subsurface records of earlier events are fragmentary. Dating of Little Ice Age (LIA) glacier maxima along the transect shows an extreme range from the 13th century (Alaska Range) to the present (mid1990s, Glaciar Pio XI, Chile) although at most sites the LIA $_{\max }$ occurred in the 18th or 19th centuries. Correlation of earlier events involves uncertainties relating to

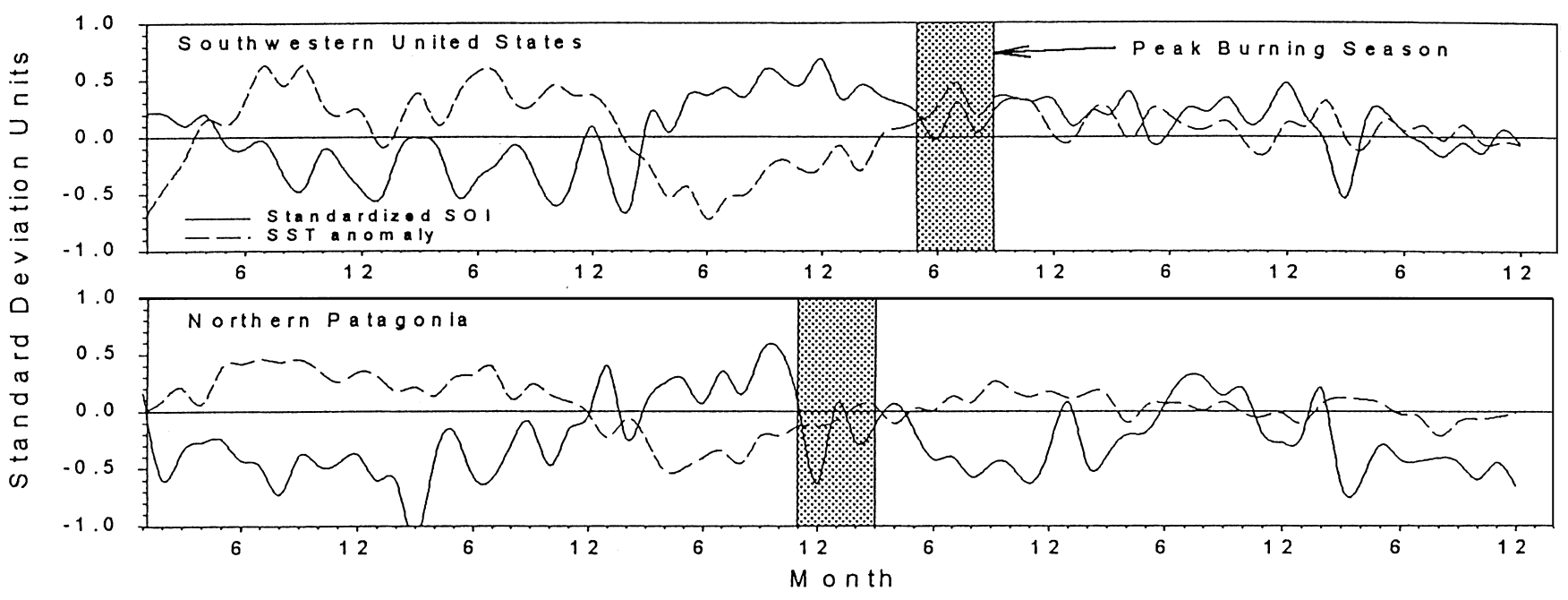

Fig. 7. Mean monthly standardized Southern-Oscillation Indices (SOI, Darwin-Tahiti, solid lines) and Sea Surface Temperature anomalies (SST, from Niño $1+2$ Region, dashed lines) preceding, during, and following the years in which largest areas burned in the Southwestern US (1914-1987, 14 events), and the years with largest number of lightning-caused fires in Patagonia (1938-1996, 9 events). The peak burning season during the tested years is indicated by the shaded period. Note that La Niña conditions (i.e., high SOI values and cold SSTs) immediately preceded the peak burning seasons during the major fire years, while El Niño-type conditions (i.e., low SOI values and warm SSTs) generally occurred in earlier seasons and years. 
differences in temporal resolution between the dating techniques used $\left({ }^{14} \mathrm{C}\right.$, tree-rings, lichens, historical records, etc.), available dating control (e.g., limiting versus event dates) and the representativity of the available record (number and nature of sites). Glacier dynamics are primarily controlled by mass balance relationships that involve various combinations of precipitation and temperature effects and may be significantly influenced by non-climatic factors such as surging or calving behaviour. Given the wide range of glacier environments along the transect (from high altitude tropical xeric sites to cold, wet maritime areas) secure knowledge of the local

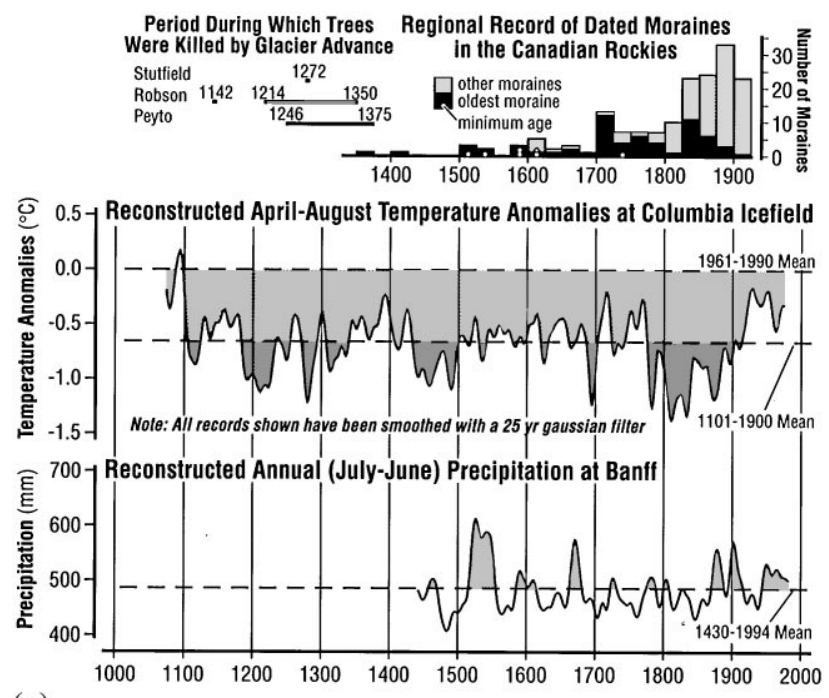

(a)

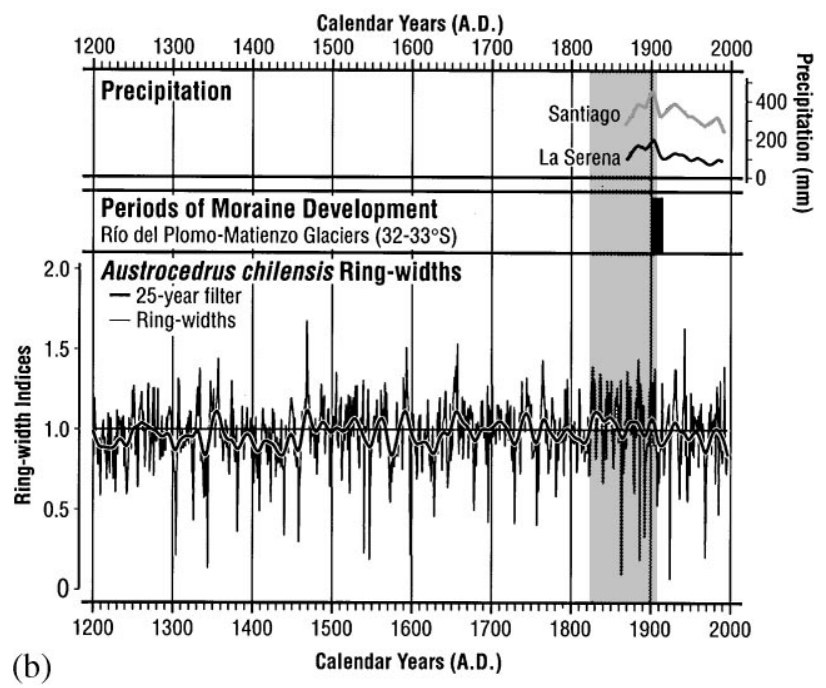

Fig. 8. (a) Comparison of the regional record of glacier fluctuations (upper panel, Luckman, in press) with tree ring reconstructed temperature (Luckman et al., 1997) and precipitation series (Watson, 1998) from sites in the Canadian Rockies. (b) Instrumental precipitation record from Santiago and La Serena, Chile (upper panel), dated moraines from the Rio del Plomo-Matienzo glaciers (central panel, Videla, 1997) and tree ring reconstructed precipitation from Austrocedrus chilensis in central Chile (updated from LaMarche et al., 1979). and regional controls of glacier mass balance are necessary to extract a climate signal from studies of past glacier fluctuations.

Two examples are presented to illustrate these points (Fig. 8a). The regional moraine record from the Canadian Rocky Mountains (66 glaciers) can be compared with tree-ring-based reconstructed summer temperatures and annual precipitation from sites within the region. The correspondence of moraine building periods with the transition from colder to warmer summers suggests that summer temperatures are the primary control of glacier fluctuations in this region. There are no obvious glacier-precipitation relationships although glacier advances in the early 1700 s and mid-20th century may be related to a combination of higher precipitation and lower temperatures. The $\mathrm{LIA}_{\max }$ of the Rio PlomoMatienzo Glaciers in Argentina is dated from historic records and coincides with a sharp decrease in precipitation at stations west of the Andes in Central Chile (Fig. 8b). The ring width record from Austrocedrus chilensis mirrors the precipitation record, indicating the LIA $_{\text {max }}$ came at the end of an extended period of higher precipitation. In this example periods of glacier advance correspond with periods of sustained higher precipitation.

The review of available data along the transect suggests a broad synchroneity in the initiation and timing of LIA glacial events with initial glacier advances being seen ca 13-14th centuries in the Northern Hemisphere and Patagonia, little evidence for extended glaciers during the 14-16th centuries and the "classic" LIA advances during the 17th-early 20th centuries. In detail however, particularly at the decadal level, there is considerable variability in both the relative extent and timing of events and the dating of the LIA maximum position. These differences reflect varying dominance of precipitation and temperature controls of mass balance as well as non-climatic influences on glacier behaviour. There remains a significant need for detailed well-dated records of glacier fluctuations coupled with a better understanding of the factors that control glacier mass balance.

\section{Glaciation and Climate Change in the American Cordillera}

The sequence of alpine glacial events in the Americas has been used to investigate several important topics in inter-hemispheric climate change on glacial-to-interglacial time scales. For example, the extent of snowline depression in the tropics has been used as a proxy to determine the amount of temperature change during the last glacial maximum (LGM) (e.g., Klein et al., 1999). Glacial events have also been used to investigate the occurrence of high-resolution climatic events in North 
and South America such as the Heinrich Events (Lowell et al., 1995; Benson et al., 1996, 1998) and the Younger Dryas (Osborn et al., 1995). All of these investigations of inter-hemispheric climate coupling require tight absolute age control of glacial events. Generally, the chronology is provided by radiocarbon ages of organic material that either accumulated before or after the glacial event. Thus these ages provide maximum and minimum limiting ages, respectively, for the glacial deposits that they are associated with. The accumulation of cosmogenic isotopes in rock surfaces has also been used to date glacial events in North America (e.g., Phillips et al., 1990, 1997; Gosse et al., 1995).

The amount of temperature depression in the tropics during the LGM has been debated ever since CLIMAP (1981) provided a reconstruction of glacial-age sea-surface temperatures (SST). Webster and Streten (1978) and Rind and Peteet (1986) showed that there were major discrepancies between the temperature depression in the tropics inferred from snowline depression and the relatively minor changes in SST. CLIMAP's target date for their reconstructions was $18{ }^{14} \mathrm{C}$ kyr BP (thousands of radiocarbon years before present) when the maximum ice volume in the Northern Hemisphere was reached. The question remains, however, if the $\sim 1 \mathrm{~km}$ of snowline depression in the tropics occurred during marine isotope stage 2 or not. Some have argued that temperatures may have been cold during the LGM, but that conditions were too dry to promote maximum glaciation during marine isotope stage 2 or at the LGM as defined by CLIMAP (e.g., Van der Hammen et al., 1981; Clayton and Clapperton, 1997). However, there are also minimum ages for deglaciation in Peru and Bolivia that would not refute a glacial maximum during marine isotope stage 2 (e.g., Rodbell, 1993; Seltzer, 1994a). Thus the timing of maximum glaciation in the tropical cordillera remains an open issue.

Recent glacial-geologic investigations have provided strong evidence for inter-hemispheric coupling of climate change during the Heinrich Events (Bond et al., 1992, 1995). The best dated glacial sequence in South America comes from the Chilean Lake District (Lowell et al., 1995). Here wood and other organic remains are intercalated with glacial diamictons and outwash deposits. Close age bracketing of the glacial deposits suggests that even though this site is in the Southern Hemisphere and the glacial dynamics were probably much different than the continental glaciers surrounding the North Atlantic, there is good correspondence on the level of individual Heinrich Events. In lacustrine deposits immediately east of the Sierra Nevada of California proxies for glacial activity: primarily magnetic susceptibility, organic carbon, and the geochemistry of the sediments, indicate repeated glacial advances in synchrony with the Heinrich Events (Benson et al., 1996, 1998).
The Younger Dryas has also been looked at in detail to determine if it was an inter-hemispheric glacial event (e.g., Osborn et al., 1995). The best dated sites in the American cordillera are in the Canadian Rockies and the Ecuadorian Andes. However, most of the results provide bracketing ages of glacial advances between 12 and 10 ${ }^{14} \mathrm{C}$ kyr BP, which may or may not be related to the Younger Dryas event of the North Atlantic region.

Glacial events provide a strong means to correlate climate events over large distances. Even though dynamical considerations may cause some glaciers not to respond directly to climatic change, in general, glacial advance is related to changes in mass balance and therefore climate (e.g., Seltzer, 1994b). The challenge is to provide unambiguous, absolutely dated chronologies in order to make continental and inter-hemispheric comparisons.

\section{Late Pleistocene Lake Records}

There are basically three ways in which the atmosphere, generally through the distribution, temporal residence, and interaction of air masses, significantly affects lakes: (1) by governing the amount and seasonality of moisture sources, including loss of moisture through evaporation and lags in moisture delivery as a result of snow accumulation and subsequent melting. (2) by controlling the annual and seasonal variations in temperature as determined by distribution, interaction, and residence times of air masses. (3) by directing the amount and seasonality of wind stress as related to temperature gradients and residence or passage of air masses. Interpretation of paleolimnological records should seek such generalized causal climate-based relations if lake records are to contribute significantly to the understanding of climate change.

Lakes respond to climate changes affecting water balance (precipitation and evaporation related to winds and temperature) by rising and falling, and (or) by becoming fresher or more saline. These changes can be complicated by the interplay between surface- and ground-water sources of differing chemistry and volumes and by loss of lake water to the ground-water system. Variable lags between snow melt and runoff also have important consequences to lake biology. Temperature obviously affects the amount and seasonality of ice cover in temperate lakes, and so influences stratification, nutrient dynamics and the life histories of many organisms. Wind, apart from its role in enhancing evaporation, determines the length and strength (depth) of circulation in combination with temperature effects on water density. Wind and runoff characteristics thereby play a critical role in nutrient dynamics of lakes, but can indirectly impact the light regime of lakes by turbidity. Cloud and snow cover can directly vary the amount of light a lake receives. 
The records summarized in Fig. 9 represent a selection of sites between Alaska and southern Patagonia that lie near the western margin of North and South America. Site selection aims at highlighting climate changes related to or buffered by the Pacific Ocean in an attempt to simplify, if possible, climate-lake relations along the PEP 1 transect. These variable and sometimes detailed records based on assorted paleolimnological proxies have been subjectively distilled into histograms simply representing deviation from modern limnological environments, generally expressed in terms of hydrological balance; typically high vs. low lake levels, fresh vs. saline water or warm vs. cold conditions. Despite many irregularities in dating, proxy interpretation, and site analysis, a number of records along the PEP 1 transect contain paleolimnological information since full-glacial times that identifies the past distribution and strength of largescale climate processes affecting lake levels and other limnological processes. Viewed from this general, lowresolution perspective, lake histories along the transect can be grouped into four interacting climate scenarios.

(1) Unglaciated Arctic lake systems witness, by $16 \mathrm{k}$, progressive warming related to deglaciation by a reduction in the thickness and seasonal extent of ice cover and a concomitant increase in productivity. Additional records could certainly show other climate / lake interactions related to changing moisture sources and winds, changing seasonality of insolation, and varying styles of land / lake interactions mediated by vegetation and erosion changes under climate control.

(2) Mid latitude, western North American lakes, including Mexico, responded by $16 \mathrm{k}$ to an intensification and greater persistence of westerly moisture delivered by storm tracks forced south by climate changes that encouraged the growth of ice sheets and southerly displacement of polar air masses.

(3) South of central Mexico and north of Lago Titicaca in southern Bolivia $\left(16^{\circ} \mathrm{S}\right.$.), all lacustrine systems seem to have been low or dry in the full-glacial, apparently as a consequence of substantially reduced ITCZ / trade wind circulation systems that today provide moisture to these basins. Late-glacial moisture increases characterized the western sites, whereas the arrival of easterly moisture approximately coincides with the beginning of the Holocene at the eastern lake sites (Lago Valencia and Laguna de los Lirios). The spatial coherence and climatic significance of this apparent gradient must await additional well-dated records.

(4) Records from southern South America at latitudes $16-23.5^{\circ} \mathrm{S}$ were also low or dry during the full glacial, but record significant high-stands during the late glacial. The most notable of these (the Tauca lake stage) occurred at Lago Titicaca and Salar de Uyuni, but apparently not at Laguna Lejia $\left(23.5^{\circ} \mathrm{S}\right.$.) which rose to higher than modern levels only during the latest glacial and early Holocene. The reasons for this are not understood at present, but may relate to cold ocean temperatures and insufficient moisture transport from the east until the early Holocene at the latitude of Laguna Lejia.

(5) Between $30-41^{\circ} \mathrm{S}$. latitude, two lake systems, Salinas del Bebedero and Cari Laufquen Grande document high lake stages during the full and early late glacial and lower levels thereafter. These changes may reflect moisture sources related to outbreaks of polar air and the generation of low-pressure systems in the western Atlantic. Such processes would have been most active and intense in the winter, and precipitation derived from them could have maintained lakes in otherwise arid environments. Cooler overall temperatures clearly contributed to a positive moisture balance.

(6) South of latitude $45^{\circ} \mathrm{S}$., Lago Cardiel is the only studied representative of lake systems with sediment and geomorphic evidence of past lake stages higher than modern. Lago Cardiel has no record of full- or late-glacial stages higher than its present. If it was indeed low during the full- and late-glacial, the reason may be ascribed to generally cold temperatures and the inability of polar outbreaks to transport moisture from cold adjacent oceans landward. If so, higher than modern levels in the early Holocene could reflect warm ocean sources of moisture finally reaching relevant latitudes to the south and the onset of westerly stormtrack activity at these latitudes.

At this scale of resolution, it appears that past interhemispheric climate interactions in the western hemisphere are synchronous and linked, at least indirectly. The massive Laurentide / Cordilleran ice sheet or those processes that sustained it may have forced climate changes throughout the western Northern Hemisphere and perhaps even as far south as central South America. The southerly displacement of westerly storm tacks in North America has been modeled (Kutzbach, 1987) and western North America lake records register this displacement. Easterly precipitation sources associated with the ITCZ diminished in importance or disappeared altogether perhaps as a consequence of general cooling in tropical and subtropical regions. At least no records in northern and central South America studied so far appear to document increased easterly (ITCZ) precipitation during full- or early late-glacial times. To account for dry conditions during the full- and late-glacial periods, the ITCZ is supposed to have resided farther north by South American workers (e.g. Martin et al., 1997) and farther south by North American workers (e.g. Bradbury, 1998). Perhaps the resolution to this problem lies in the weakening, restriction, and redirection of easterly 


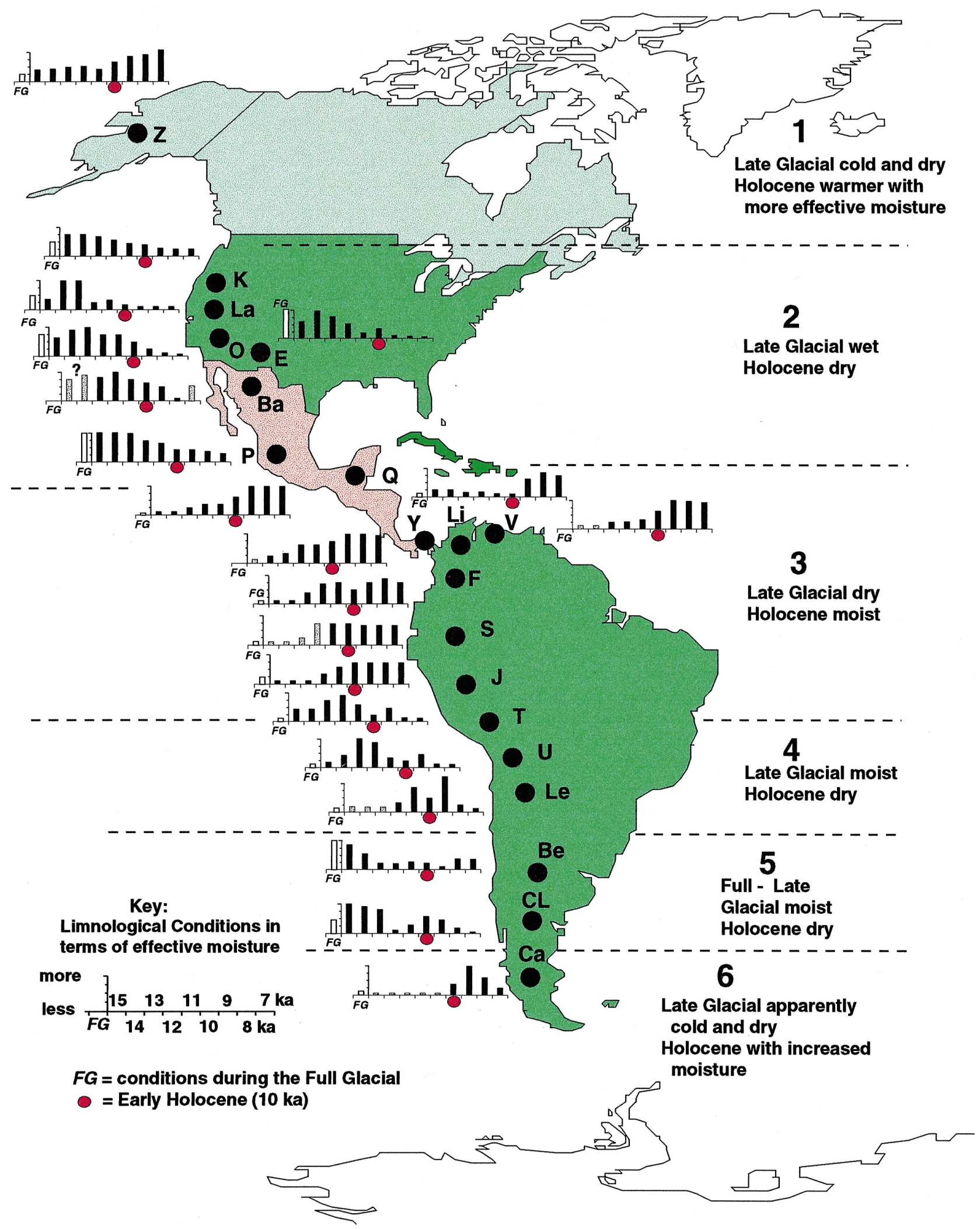

Fig. 9. Location of sites with paleolimnological records spanning full- lateglacial and early Holocene times. Histograms represent lacustrine conditions (lake levels, salinity, etc.) expressed in dimensionless terms of effective water balance as compared to modern conditions. FG (unfilled histograms) represent full-glacial interval; shaded histograms represent questionable interpretations. Letters indicate site name: Z: Zagoskin Lake, AK; K: Klamath Lake CA; La: Lake Lahontan, NV; O: Owens Lake, CA; E: Estancia Lake, NM; Ba: Cuenca de Babicora, Mexico; P: Lago de Patzcuaro, Mexico; Q: Laguna Quexil, Mexico; Y: La Yeguada, Panama; Li: Laguna Los Lirios, Venezuela; V: Lago de Valencia, Venezuela; F: Laguna de Fuquene, Colombia; S: Laguna Surucucho; J: Laguna Junin, Peru; T: Lago de Titicaca, Peru; U: Salar de Uyuni, Bolivia; Le: Laguna Lejia, Chile; Be: Salinas del Bebedero, Argentina; CL: Cari Laufquen Grande, Argentina; Ca: Lago Cardiel, Argentina. 
moisture sources by the effects of mobile polar highs as suggested by Leroux (1993) and Marengo and Rogers (1999).

Full- and late-glacial high lake levels in southern South America as a result of intensified and more northerly displaced westerly moisture sources conflicts with pollen evidence at the same latitude west and east of the Andes. As a consequence, moisture from the south-west Atlantic, related to outbreaks of polar air originating over a very cold Antarctica may have provided a positive hydrologic balance fore these lacustrine systems. The synchroneity of mid-latitude lake level records in both hemispheres probably relates to much colder polar climates ultimately thought to be caused by reduced heat transport to the north and south related to reduced thermohaline circulation controlled by glacial melt-water processes in the North Atlantic Ocean (e.g., Alley, 1995).

\section{Conclusions}

To achieve a meaningful understanding of inter-hemispheric and ultimately global linkages of past climates by comparison of paleoclimate proxy records, two preconditions need to be fulfilled: (1) Each proxy record's local and regional response to environmental and climate variability needs to be understood; and (2) The linkages of the modern climate system between the regions to be compared need to be taken into account. This approach has been especially successful in analyzing the interhemispheric linkages of ENSO variability and its cause. By combining time series analysis with correlation field analysis, e.g., it became evident that although the temporal relationship did not remain constant between the records, spatial coherence continued. Using a similar approach for records with century to millennial scale resolution, and for intervals when boundary conditions were substantially different, we ultimately may be getting closer to solving questions as to the cause of climate change.

\section{References}

Alley, R.B., 1995. Resolved: the Arctic controls global climate change. In: Smith, W.O., Grebmeier (Eds.) Arctic Oceanography: Marginal Ice Zones and Continental Shelves. Coastal and Estuarine Sciences, Vol. 49. American Geophysical Union, pp. 263-283.

Baumgartner, T.R., Ferreira, V., Cowen, J., Soutar, A., 1991. Reconstruction of a twentieth century varve chronology from the central Gulf of California. In: Dauphin, J.P., Simoneit, B. (Ed.), The Gulf and Peninsular Province of the Californias, American Association of Petroleum Geologists, Memoir, 47 pp. 606-616.

Baumgartner, T.R., Soutar, A., Ferreira-Bartrina, V., 1992. Reconstruction of the history of Pacific sardine and northern anchovy populations over the past two millennia from sediments of the Santa Barbara Basin. California Cooperative Oceanic Fisheries Investigation, Report 33, pp. 24-40.
Benson, L.V., May, H.M., Antweiler, R.C., Brinton, T.I., Kashgarian, M., Smoot, J.P., Lund, S.P., 1998. Continuous lake-sediment records of glaciation in the Sierra Nevada between 52,600 and 12,500 ${ }^{14} \mathrm{C}$ yr BP. Quaternary Research 50, 113-127.

Benson, L.V., Burdett, J., Kashgarian, M., Lund, S., Phillips, F.M., Rye, R.O., 1996. Climatic and hydrologic oscillations in the Owens Lake Basin and adjacent Sierra Nevada. California. Science 274, 746-749.

Bond, G., Heinrich, H., Broecker, W., Labeyrie, L., McManus, J., Andrews, J., Huon, S., Jantschik, R.C., Simet, S.C., Tedesco, K., Klas, M., Bonani, G., Ivy, S., 1992. Evidence for massive discharges of icebergs into the North Atlantic Ocean during the last glacial period. Science 360, 245-249.

Bond, G.C., Lotti, R., 1995. Iceberg discharges into the North Atlantic on millennial time scales during the last glaciation. Science 267 , 1005-1009.

Bradbury, J.P., 1998. Sources of Glacial Moisture in Central America. Quaternary International 43/44, 97-110.

Clayton, J.D., Clapperton, C.M., 1997. Broad synchrony of a late-glacial glacier advance and the highstand of paleolake Tauca in the Bolivian Altiplano. Journal of Quaternary Science 12, 169-182.

CLIMAP, 1981. Seasonal reconstructions of the Earth's surface at the last glacial maximum. Geological Society of America Map and Chart Series, MC-36, Geological Society of America.

Dettinger, M.D., Cayan, D.R., Diaz, H.F., Meko, D.M., 1998. North-south precipitation patterns in western North America on interannual-to-decadal timescales. Journal of Climate 11, 3095-3111.

Diaz, H.F., Pulwarty, R.S., 1994. An analysis of the time scales of variability in centuries-long ENSO-sensitive records in the last 1000 years. Climatic Change 26, 317-342.

Gosse, J.C., Klein, J., Evenson, E.B., Lawn, B., Middleton, R., 1995. Beryllium-10 dating of the duration and retreat of the last Pinedale glacial sequence. Science 268, 1329-1333.

Kaplan, A., Cane, M.A., Kushnir, Y., Blumenthal, B., Rajagopalan, B., 1997. Analyses of global sea surface temperature 1856-1991. Journal Geophysical Research 101, 22 599-22 617.

Kitzberger, T., Veblen, T.T., 1998. Influences of humans and ENSO on fire history of Austrocedrus chilensis woodlands in northern Patagonia. Argentina. Ecoscience 4, 508-520.

Klein, A.G., Seltzer, G.O., Isacks, B.L., 1999. Modern and last glacial maximum snowlines in the central Andes of Peru. Bolivia, and Northern Chile. Quaternary Science Reviews 18, 65-84.

Kutzbach, J.E., 1987. Model simulations of the climatic patterns during the deglaciation of North America. In: Ruddiman, W.F., Wright, H.E. (Eds.), North America and Adjacent Oceans During the Last Deglaciation. The Geology of North America K-3, Geological Society of America, pp. 425-446.

LaMarche, V.C., Holmes, R.H., Dunwiddie, P.W., Drew, L.G., 1979. Tree-ring chronologies of the Southern Hemisphere 2. Chile. Chronology Series 5. Laboratory of Tree-Ring Research, University of Arizona, Tucson.

Leroux, M., 1993. The mobile polar high: a new concept explaining present mechanisms of meridional air- mass and energy exchanges and global propagation of paleoclimatic changes. Global Planetary Change 7, 69-93.

Lowell, T.V., Heusser, C.J., Andersen, B.G., Moreno, P.I., Hausser, A., Heusser, L.E., Schluchter, C., Marchant, D.R., Denton, G.H., 1995. Interhemispheric correlation of late Pleistocene glacial events. Science 269, 1541-2549.

Luckman, B.H., 1999. The Little Ice Age in the Canadian Rockies. Geomorphology, in press.

Luckman, B.H., Briffa, K.R., Jones, P.D., Schweingruber, F.H., 1997. Tree-ring based reconstruction of summer temperatures at the Columbia Icefield, Alberta, Canada, A.D. 1073-1983. The Holocene 7, 375-389. 
Luckman, B., Villalba, R., 1999. Assessing the synchroneity of glacier fluctuations in the western cordillera of the Americas during the last millennium. In: Markgraf, V. (Ed.), Inter-Hemispheric Climate Linkages Academic Press, San Diego, in press.

Mann, M.E., Park, J., 1994. Global-scale modes of surface temperature variability on interannual and century time scales. Journal Geophysical Research 99, 25 819-25833.

Marengo, J.A., Rogers, J., 1999. Cold fronts and polar air outbreaks in the Americas, assessments and impacts during modern climate, and past climate evidences. In: Markgraf, V. (Ed.), Inter-Hemispheric Climate Linkages Academic Press, San Diego, in press.

Markgraf, V., 1998. Researchers investigate inter-hemispheric climate linkages in the Americas and their societal effects. EOS Transactions, American Geophysical Union 79, 371-378.

Martin, L., Bertaux, J., Corrège, T., Ledru, M.-P., Mourguiart, P., Sifeddine, A., Soubiès, F., Wirrmann, D., Suguio, K., Turc, B., 1997. Astronomical forcing of contrasting rainfall changes in tropical South America between 12,400 and $8800 \mathrm{cal} \mathrm{yr} \mathrm{B.} \mathrm{P.} \mathrm{Quaternary}$ Research 47, 117-122.

Osborn, G., Clapperton, C., Davis, P.T., Reasoner, M., Rodbell, D.T., Seltzer, G.O., Zielinski, G., 1995. Potential glacial evidence for the Younger Dryas event in the cordillera of North and South America. Quaternary Science Review 14, 823-832.

Ortlieb, L., Escribano, R., Follegati, R., Zuñiga, O., Kong, I., Rodriguez, L., Valdes, J., Iratchet, P., Guzman, N., Ocean-climatic changes during the last 2000-years in a hypoxic marine environment of Northern Chile, Revista Chilena de Historia Natural, in press.

Phillips, F.M., Zreda, M.G., Gosse, J.C., Klein, J., Evenson, E.B., Hall, R.D., Chadwick, O.A., Sharma, P., 1997. Cosmogenic ${ }^{36} \mathrm{Cl}$ and ${ }^{10} \mathrm{Be}$ ages of Quaternary glacial and fluvial deposits of the Wind River Range Wyoming. Geological Society of America Bulletin 109, 1453-1463.

Phillips, F.M., Zreda, M.G., Smith, S.S., Elmore, D., Kubik, P.W., Sharma, P., 1990. Cosmogenic Chlorine-36 chronology for glacial deposits at Bloody Canyon, eastern Sierra Nevada. Science 248, 1529-1532.

Rind, D., Peteet, D., 1986. Terrestrial conditions at the last glacial maximum and CLIMAP sea-surface temperature estimates: Are they consistent?. Quaternary Research 24, 1-22.

Rodbell, D., 1993. Subdivision of late Pleistocene moraines in the Cordillera Blanca, Perú based on rock weathering features, soils and radiocarbon dates. Quaternary Research 39, 133-143.
Seltzer, G.O., 1994a. A lacustrine record of late-Pleistocene climatic change in the subtropical Andes. Boreas 23, 105-111.

Seltzer, G.O., 1994b. Climatic interpretation of alpine snowline variations on millennial time scales. Quaternary Research 41, 154-159.

Soutar, A., Crill, P.A., 1977. Sedimentation and climatic patterns in the Santa Barbara Basin during the 19th and 20th centuries. Geological Society of America Bulletin 88, 1161-1172.

Soutar, A., Isaacs, J.D., 1974. Abundance of pelagic fish during the 19th and 20th centuries as recorded in anaerobic sediment off the Californias. Fishery Bulletin 72, 257-294.

Stocker, T.F., Mysak, L.A., 1992. Climatic fluctuations on the century time scale: A review of high- resolution proxy data and possible mechanisms. Climatic Change 20, 227-250.

Swetnam, T.W., Betancourt, J.L., 1990. Fire-Southern Oscillation relations in the Southwestern United States. Science 24, 1017-1020.

Swetnam, T.W., Betancourt, J.L., 1998. Mesoscale disturbance and ecological response to decadal climatic variability in the American Southwest. Journal of Climate 11, 3128-3147.

van der Hammen, T., Barelds, T., De Jong, H., De Veer, A.A., 1981. Glacial sequence and environmental history in the Sierra Nevada Cocuy (Colombia). Palaeogeography Palaeoclimatology Palaeoecology 32, 247-340.

Veblen, T.T., Kitzberger, T., Villalba, R., Donnegan, J., 1999. Fire history in northern Patagonia: The roles of humans and climatic variation. Ecological Monographs 69, 47-68.

Videla, M.A., 1997. Neoglacial advances in the Central Andes, Argentina, during the last centuries. Quaternary of South America and Antarctic Peninsula 10, 55-70.

Villalba, R., D’Arrigo, R.D., Cook, E.R., Wiles, G., Jacoby, G.C., 1999. Decadal-scale climatic variability along the extratropical western coast of the Americas inferred from tree-ring records. In: Markgraf, V. (Ed.), Inter-Hemispheric Climate Linkages and their Societal Effects Academic Press, San Diego, in press.

Watson, E., 1998. Dendroclimatic Reconstruction of precipitation in British Columbia and Alberta, M.Sc Thesis, University of Western Ontario, 220.

Webster, P.N., Streten, N., 1978. Late Quaternary ice age climates of tropical Australasia, interpretation and reconstruction. Quaternary Research 10, 279-309.

Zhang, Y., Wallace, J.M., Battisti, D.S., 1997. ENSO-like interdecadal variability: 1900-93. Journal of Climate 10, 1004-1020. 